Article History:

Submitted:

17 January 2022

Reviewed:

24 January 2022

Edited:

27 January 2022

Article Accepted:

28 January 2022

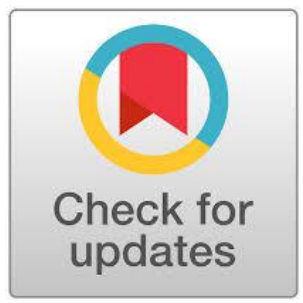

\section{Learning English through International Student Exchange Programs: English Education Department Students' Voices}

\author{
Suryanto Suryanto ${ }^{1^{*}}$, Betha Labova Ayuza ${ }^{1}$, Noor Ahnis \\ Othman $^{2}$
}

${ }^{1}$ English Education Department, Faculty of Language

Education, Universitas Muhammadiyah Yogyakarta, Indonesia

${ }^{2}$ Academy of Language Study, Universiti Teknologi MARA

(UiTM), Malaysia

${ }^{*}$ Corresponding author email: suryanto@umy.ac.id

DOI: https://doi.org/10.18196/ftl.v7i1.13717

\begin{abstract}
English language learning is a process that students must go through in order to reach the optimum level of proficiency in the language. International student exchange programs are activities that might assist students in practicing and improving their English. The purposes of this study were to investigate the benefits and to identify the challenges of participating in an international student exchange program while studying English at the English Language Education Department of an Islamic Private University in Yogyakarta. The research design for this study was a qualitative descriptive one. The data for this study were gathered through interviews. Three students from the English Language Education Department of a private Islamic university in Yogyakarta participated in this investigation. The first finding concerned the advantages of participating in an international student exchange program while studying English. It shown that participating in international student exchange programs aided students in making foreign friends, interacting with native English speakers, practicing, and improving their English abilities, and boosting their self-confidence. The second result concerned the challenges associated with participating in an international student exchange program to improve their English. It demonstrated that students who participated in an international student exchange program failed to engage with local people outside of school and experienced culture shock. All associated parties, including students, host universities, university senders, and the program's committee, should organize and execute the program's activities with care and attention, beginning with the program's planning, preparation, deployment, evaluations, and follow-up.
\end{abstract}

Keywords: Students exchange program; Learning English language; practice English in student exchange 


\section{Introduction}

Students must become active participants in the English teaching and learning process in order to succeed in their studies. As being active students, they entail participating in both academic and extracurricular activities. Students should participate in classroom activities. They complete teacher-assigned exercises, present subjects in front of the class, study the materials, and discuss solutions to specific difficulties or other needed classroom tasks.

Students should also learn things outside of the classroom. They can become members of organizations, volunteer at big events, attend international conferences, and participate in foreign student exchange programs. Joining organization entails engaging in activities outside of the classroom. Numerous students wish to join the organization in order to get experience and expertise. Additionally, the students also want to become volunteers at several major events. Students volunteer to be personally involved in a social movement, whether through governmental, private, or university organizations. Also, one of the most beneficial activities for students is to participate in an international student exchange program.

International students exchange programs enable students to study at other universities in other countries. To participate in an international exchange program, students must complete various stages, including creating curriculum vitae, writing a motivation letter, and generating an academic transcript. Furthermore, students have a variety of motives for participating in an international student exchange program. Among these is the desire for pupils to enhance their English-speaking abilities. Another reason is that students wish to broaden their horizons by immersing themselves in an international academic environment. Moreover, they are eager to strengthen their communication abilities for the sake of their chances by participating in an international student exchange program.

According to Lindsey (2005), students who participate in foreign student exchange programs gain chance to improve their English language abilities. Other scholars suggest similar concepts, namely that studying a language in a country where the language is spoken is extremely helpful for language acquisition, particularly for the development of oral skills. (Llanes et al., 2016). Additionally, they said that the influence of international student exchange programs can help develop English as a second language in countries where English is widely spoken. For instance, Spanish students studying in the Netherlands or Germany with English as a second 
language (Llanes et al., 2016). In this context, the students participate in an exchange program for foreign students in a country where English is a second language. Students who join an exchange program in countries where English is a first language still possess opportunities to practice their English as the programs mostly embrace and implement the idea of English as international language (McKay, 2018) where English takes a role as a means of communication (Takehara et al., 2018), lingua franca (Llanes et al., 2016; Martin-Rubió \& Cots, 2018), and as means of instruction (Zhang, 2018).

A preliminary evaluation of students who had participated in an international student exchange program found that the program provided several benefits to the students. To begin, students can strengthen their English language abilities. The improvement covers the development of the students' primary abilities in the English language: listening, speaking, reading, and writing. Second, students can develop their English language skills. They met with international visitors and had the opportunity to develop their language skills in languages other than English. Finally, pupils can boost their self-esteem and motivation. Students that participate in international student exchange programs prepare the fight independently and are not reliant on others. Such behaviors demonstrate that participation in foreign student exchange programs benefits students' self-confidence and motivation (Jackson, 2017). According to Llanes et al. (2016), students developed confidence in using English as a second language by participating in an international student exchange program.

Apart from the benefits, students who participate in an international student exchange program confront challenges (Busche, 2017). The first challenge is adapting to the language spoken in the exchange country. When the destination country does not speak English as the first language, participants in international exchange programs may have communication issues with the local populace (Johnson et al., 2018). Students face difficulties communicating with residents outside the school. This condition may impair students participating in international student exchange programs' learning processes. Finally, students may encounter culture clash as a result of their stay in an unfamiliar location (Johnson et al., 2018). The limited number of the study on this topic in the context of this research encourage the researchers to choose an international student exchange program in the process of Learning English language 
to be the topic of the research, especially in English Language Education Department of Islamic Private University in Yogyakarta.

\section{Literature Review}

Learning English language is a process that takes place to master English as good as possible. Students need extensive and close interactional contacts to practice the language. Various endeavours can be provided by educational institutions to facilitate students in this process to obtain language knowledge and skills. They can perform learning activities in real life, interactive situations that can allow students to gain rational and meaningful learning practices (Huang et al., 2016). International students exchange program constitutes facilitative activities that enable students to be immersed in the real language learning practices (Berg et al., 2012).

\section{International Students exchange program}

International students exchange program is a program that is provided by universities, in which the students from a university are provided with the opportunity to study to universities in other countries. International students exchange program is now a common activity in many schools of social work (Gammonley et al., 2007). International students exchange program has been a part of academic culture from university program (Vögtle \& Windzio, 2016). According to Thompson and Lee (2014), international students exchange program contributes to the improvement of Learning English language, but it does not always guarantee improvement in the target language when the students fail to engage with inside and outside campus communities(Wilkinson, 2000). The length of time staying in other countries is necessary for gaining experiences that are linguistically useful (Isabelli-García et al., 2018).

\section{The Benefits of Joining International Students exchange program}

There are several benefits that the students get when they join international students exchange program. They include having ample opportunities to practice English (Berg et al., 2012), building international networks (Hendrickson, 2018), connecting with native English speakers (Hernandez, 2016), improve students' employment prospects (Waibel et al., 2018), enhancing cross-cultural competence (Earnest et al., 2016; Krishnan et al., 2017), and cross- 
cultural awareness and sensitivity Improving English language skills (Hernandez, 2016; Thompson \& Lee, 2014), and increasing self-confidence (Bretag \& van der Veen, 2017).

\section{Ample opportunities to practice English}

The most important thing when students choose to join international students exchange program is that their language skills will grow and improve, especially their English language skills. The students will speak using English before they learn the local language of the country. Inevitably, they must speak in English to be able to communicate with other people. Although maybe at first, they are not too proficient, they will get used to speaking English and become proficient. According to Trentman (2013) while studying in Egypt, students often have difficulty communicating with local friends, and they spend more time using English than Arabic. Llanes et al. (2016) stated that the important aspect regarding the second language that was found after participating in the student exchange program was oral fluency. It means that students are able to have ample practice their English while joining international students exchange program that facilitate their language acquisition (DeKeyser, 2018).

\section{Building international networks}

Getting international networks is one of the benefits of joining international students exchange program. When students choose to study in another country, people who study there do not only come from the country itself, but also from various other countries. According to Bachner and Zeutschel (2009), joining international students exchange program helps students to add more friends. The statement is also in line with Crossman and Clarke (2010), who stated that students who follow international student exchange programs receive various types of knowledge, connections, and ways of learning that cannot be obtained if they remain in their own country and practice their language skills. Even, a study noted that network established by the student exchange program remain stable for long periods of time (Vögtle \& Windzio, 2016)

\section{Connecting with native English speakers}

The best way to practice a language is to connect directly with native speakers of the language. In this context, there are native speakers of English. While joining international students exchange program, students can interact directly with native English speakers. According to Barrow and Pithers (2016), interaction with native speakers of English helps students become proficient in English. Additionally, based on researchers' experience while 
joining international students exchange program, the researchers was able to meet and communicate directly with native English speakers in the foreign university. In the foreign university, there were not only local students, but there were also foreign students in various countries.

\section{Improve students' employment prospects}

Education and labor market allocations are seen as two-sided matching procedures between applicants' talents and employer employment requirements. Employers analyze potential workers and employees evaluate potential employers to enhance both educational and employment performance. The most prevalent hypotheses on how education is causally connected to job assignment are human capital and job employment (Waibel et al., 2018).

A thing to consider is that economists often depict mobility and education as investments in one's productive capacity. Investing in human capital is rationally chosen if it will provide long-term economic gains. To acquire human capital may be the main motivation for students to move abroad like joining international student exchange program (Waibel et al., 2018). Foreign language learning, personal growth, and intercultural and mobility abilities are all improved during study abroad. On worldwide labor markets, this human capital is prized for its global knowledge, self-initiative, and personal accountability (Waibel et al., 2018).

\section{Enhancing cross-cultural competence}

A study compared study abroad and domestic student cultural abilities to assess the influence of study abroad programs in psychology. Four hundred and forty-four undergraduate students from various disciplines performed pre-post Cross-Cultural Adaptability Inventory assessments. Study abroad students showed stronger emotional resilience, perceptual acuity, and cultural adaptability than home students (Earnest et al., 2016).

Another study sought to assess if an opportunity for experiential learning, especially a study tour, would increase potential educational leaders' intercultural competence and push them to broaden their own cultural awareness and attitude. Participants in an Educational Leadership graduate program offered the opportunity to study abroad to improve their cultural competence. They were then asked to complete a survey measuring metacognition, cognition, motivation, and behavior. They were also asked to reflect on how the encounter influenced their own cultural understanding and conduct. The study tour participants were aware of their cultural 
Journal of Foreign Language Teaching and Learning

Volume 7, No. 1, January 2022

Available online at: https://journal.umy.ac.id/index.php/FTL/issue/view/833

e-ISSN: 2580-2070, p-ISSN: $2527-7650$

competency and compared their own cultural norms with those of the study tour destination.

Participants gained significant cultural awareness (Krishnan et al., 2017)

\section{Improving English language skill}

Studies have indicated that students who spend at least a semester abroad learn a second language better. A study explores the link between students' speaking skill increases and their target language use outside of class in the host setting. A two-part modified language contact profile and a pre- and post-program simulated oral proficiency interview were administered to 20 students participating in a standard short-term study abroad program in Spain. The findings indicate that students did enhance their English speaking skills (Hernandez, 2016).

\section{Increasing self-confidence}

Based on Trentman (2013), the advantage of joining international students exchange program is that it can increase students' confidence. Bretag \& van der Veen (2017) voice similar opinion stating that joining student mobility gave the students confidence in their capacity to travel and be self-sufficient. They mentioned that two students on the Indonesia study tour mentioned enhanced self-confidence as a result of mobility

\section{The Challenges of Joining International Students exchange program}

There are several challenges that students get when they join international students exchange program. The challenges of joining international students exchange program include language, transportation, assimilation, cultural and religious interactions, and identity (Gautam et al., 2016).

Language. Language barriers have been identified as a key difficulty for non-English speaking overseas students in joining international students exchange program. Academic and social success need fluency in English as a means of international communication (Meng et al., 2018). A study found that international students remain discouraged by such a perceived barrier to use their language proficiency for successful interaction with English speakers, while expressing reluctance to engage in existing opportunities to practice their language skill to make social adaption (Wright \& Schartner, 2013). The language become challenges for students as it can distance them from teachers, acquaintances, and other university family members (Gautam et al., 2016). 
Transportation. Transportation presented a distinct set of difficulties that were directly tied to the place where exchange program takes place. There was a lack of dependable mass transportation, a point raised by numerous students. The students showed that, while the university does provide a transportation system, it fails to fulfill the needs of international students. Additionally, they highlighted the difficulties associated with obtaining a driver's license and becoming habituated to driving an automobile. For them, having a car was a significant financial investment that many felt they would be unable to make (Gautam et al., 2016).

Social assimilation. Involvement in social and cultural activities can be seen as a challenge. Gautam et al. (2016) presents three different students who have such an issue. A South Asian girl possesses a problem of a major departure from her usual routine. Her residence in her home country has her own private bathroom and area. She struggled with sharing restrooms. The African student admits to feeling isolated. A student from Europe feels sad due to the change of language she pronounces due to the influence of her stay in US. Her family is shocked to hear her language. Her family believes she has changed since moving to America.

Cultural and religious interactions. Students who join mobility program are challenged with cultural and religious interaction. The conditions are portrayed by Gautam et al. ( 2016) where students from different countries encounter different challenges. Christians may freely practice their faith. They went to church and felt no prejudice or pressure because of their faith. The South Asian individual who defined themselves as a devout Muslim conveyed her experience clearly. she was surprised how pious people are at the place of her mobility program. She knew Americans were not so religious. She was invited to a bible study. She felt like folks invited her to their bible study. As Muslims, they do not invite foreigners or people of other faiths to their celebrations. But they did, and She felt great. My friend gave her a Bible. She got the impression her friend knows Islam. The students from Europe challenge by religious heterogeneities as in her home countries the religion is homogenous. These conditions provide depiction on the challenge of students to deal with culture and religious engagement. 


\section{Method}

\section{Research Design}

This study used a qualitative approach with qualitative descriptive design (Lambert, \& Lambert, 2012; Magilvy \& Thomas, 2009). According to Lambert and Lambert,( 2012) a qualitative descriptive design is a viable and acceptable research design (p. 255). This design was chosen because the researchers let the participants answer the questions based on their feeling as long as the answers in line with the information that the researchers want to get. In addition, telling an experience needs to explore further, in exploring the story the students require a deeper description, therefore qualitative descriptive is very appropriate for this research.

This study took place at English Language Education Department of Islamic Private University in Yogyakarta. English Language Education Department of Islamic Private University in Yogyakarta is suitable place to explore the students' perception in joining international students exchange program due to many students who have joined such a program. The researchers conduct research in three weeks from October 1, 2018 to November 10, 2018.

The researchers used a purposive sampling. According to Cohen, Manion, and Morrison (2011), purposive sampling focuses on particular characteristics to focus on specific purposes. This study set two criteria to choose the participants. Firstly, the students of English Language Education Department of Islamic Private University in Yogyakarta would be served as participant of this study. Secondly, the selected participants have been joining international students exchange program for at least three months, because the students have deep experiences in joining international student exchange program compared to students who are only joining international students exchange program for a few days or for week. The participants of this research consist of two female and one male of English Language Education Department Islamic Private University in Yogyakarta. The names of the participants are not mentioned. Pseudonym is used to name the participants. The pseudonyms of the participants used in this research are Okta as the first participant, Amira as the second participant, and Mukti as the third participant.

The researchers used interview as the method to collect the data from participants. Several steps were undertaken to collect data. Firstly, the researchers made the interview guidelines containing several questions that the researchers asked to the participants. Secondly, the researchers decided to choose the participants based on the characteristics set previously to 
be interviewees. Thirdly, the researchers contact the participants using WhatsApp to inform the purpose of contacting the participants and made an appointment about when and where the interview would be conducted. Fourthly, before conducting an interview, the researchers prepared some tools to support the interview process, such as an audio recorder to record participants' answers, a notebook to look at the questions, and a pen to write additional questions. Then, the researchers started the interview. The interview process was conducted in Bahasa Indonesia in order to avoid bias and every conversation that happened between the researchers and the participants. The interviews were recorded under the permission of participants.

After the interview was done, the researchers did three steps to analyse the data. There were transcribing, member checking, and coding. The first step that researchers did was transcribing the data. The researchers transcribed the recording of the interview, then the researchers gave the pseudonym to name the participants. After the data had been transcribed, the researchers did member checking to ensure the data's trustworthiness. The participants read transcription, and when they think it was not right or they need to add more information. In this step, the researchers re-examine the participants' answers in the interview to make it clear that their answers in the interview section are correct. Furthermore, the result was that respondents admitted that the transcription was the same as what they had said in the interview. Then, the next step is coding. There are three types of coding Manion, and Morrison (2011), open coding means the researchers categorized the data which has similar meaning or similar theme. The next was axial coding. The researchers categorized and identified similar idea from each participant and also the researchers identify relations among two open codes. Then the researchers picked the data use selective coding. Selective coding is a way to choose open and axial coding into the bigger categories. In other words, the researchers selected the category based on the interview questions to make a report of the research.

\section{Findings and Discussion}

This section presents the findings and discussions of this study. The findings include the benefits and the challenges of the students who join international students' exchange program 
Journal of Foreign Language Teaching and Learning

Volume 7, No. 1, January 2022

Available online at: https://journal.umy.ac.id/index.php/FTL/issue/view/833

e-ISSN: 2580-2070, p-ISSN: $2527-7650$

in the process of learning English language. The discussions are offered directly after the findings are posed.

\section{The benefits of joining international students exchange program}

In this study, the researchers found several findings related to the benefits of joining international students exchange programs The first finding is getting international networks. The second is connecting with native English speakers. The third is practicing students' English ability. The fourth is improving students' English skills. The last is increasing self-confidence. The participants sharing their voices about the benefits of joining international students exchange program are shown in the following detailed findings.

Getting international networks. The researchers found that joining international students exchange program helps students to get international networks. This was stated by all of the participants. The first statement was stated by Okta. She said, "I have more friends, and I means get international friends". She also stated, "We also get new international friends". The second statement was stated by Amira. She said, "I obtain many international connections and friends from various countries". She also stated, "At the university where I studied, there were many students from outside of Spain, very few friends were from Spain, and all of them of course cannot speak Indonesian, therefore we use English in every conversation”. The last statement was stated by Mukti. He said, "By joining this student exchange program, I can gain new friends, especially in the international scope". He also stated, "I also gathered native English speakers and other international friends". Then, Mukti also said, "Friendship networks also increase."

From the data above, joining international students exchange program can facilitate students to get international networks. Getting international networks from various countries makes students interact and communicate using English. This finding is in line with Bachner and Zeutschel (2009), who stated that students exchange programs contribute to add students' international connections. The statement is also in line with Crossman and Clarke (2010), who stated that students who take part in international students exchange program receive various types of knowledge, connection, and ways of learning that cannot be obtained if they remain in their own country, and also train students' language skills. When the students join international students exchange program, they can get new international friends and can practice their English with their international networks (Hendrickson, 2018; Vögtle \& Windzio, 2016). 
Connecting with native English speakers. Another finding in the benefits of joining international students exchange program is that it helps students to connect with native English speakers. It was stated by one participant. The participant is Mukti. He stated, "There are lecturers from the United Stated". He also stated, "We are in the same class with English native speakers". Then, "I also gathered with native English speakers".

Based on the data, the researchers found that joining international students exchange program helps students to connect with English native speakers. The finding is in line with Barrow and Pithers (2016), who stated that interactions with native English people help students to become proficient in English in a relatively shorter time. When the students join international students exchange program, it helps them to interact and communicate with native English speakers. Interacting with native English people is considered to be effective to practice English and makes students speak English in every conversation. Thus, joining international students exchange program helps students interact with native English speakers (Barrow and Pithers (2016),).

Practicing English skills. From the result of the interview, the participants of this research mentioned that joining international students exchange program can improve students' English abilities. The first statement was expressed by Okta. She said, "I have to use English in the country". She also stated, "We use English". The second statement is from Amira. She said, "The third is practicing the language". She also stated, "Whether it is practicing English". Then, she said additional statement, "The third is preparing the language knowledge to communicate in the destination country, especially preparing the English knowledge. As we know, English is an international language". She also said, "When we are in the campus environment, we talk using English intensely". The last statement is from Mukti. He said, "During the first time, we spoke using English”. He also stated, "We often used English in semester one”.

The findings showed that joining international students exchange program makes students practice their English abilities. The finding is in line with DeKeyser ( 2018) who affirmed that one semester of international study is often seen as a major opportunity for students to practice English. He also stated that students who go abroad make tremendous progress in their English-speaking skills. When the students join international students exchange 
program, it helps them to practice their English and make meaningful changes in their English abilities.

Improving students' English skills. Based on the result of the interview, the researchers obtained the data that joining international students exchange program helps students improve their English. It was stated by all of the participants. The first statement was stated by Okta. She said, "Do not forget to strengthen English as a language in a foreign country!". She also stated, "While joining the exchange program, I think my English ability also increased, because we communicated using English, especially in the campus area". The second statement was stated by Amira. She said, "I improved my English there.". She also stated, "I felt my English improving.". She also said that she took an English major in the foreign country. It made her improve her English in academic writing, because she took a reading and writing course. She also stated, "I felt that my English really improved when I got back to my country after joining the student exchange program." She also believed that her English improved because she was taught by professors who could not speak Indonesian. So, the students were required to speak and write using English. The last statement was stated by Mukti. He said, "My English quite developed.”.

The findings showed that joining international students exchange program helps students improve their English ability. The finding is in line with Andrade (2006), who stated that students show willingness to try new ways to practice improving their language skills, especially those who aim to improve their English and communicate with peers. When students join international students exchange programs, it makes them try new things to improve their English skills (Hernandez, 2016).

Increasing self-confidence. This finding showed that joining international students exchange program makes students more confident. The first statement was from Okta. She said, "We are required to dare to speak, because if we do not communicate, we cannot live". The second statement was from Amira. She stated, "We became more courageous, braver to ask and braver to be ashamed". She also stated, "It made me more confident". Amira also stated that while joining international students exchange program, students' personality will be changed, especially their mentality. The last statement is from Mukti. He said, "We dared to interact with 
local people and with other international people". He also stated, "I am willing to try new things, be more independent, and be more confident".

The statements above showed that those participants agreed that joining international students exchange program makes students increase their self-confidence. Those statements are in line with Bachner and Zeutschel (2009), who found that self-change is related to the process of student exchange programs, which refers to one's self-perception, self-confidence, behavior, and skills caused by exchange experiences. The statement is also in line with Quezada (2004), who mentioned that this international learning experience can be seen as a positive experience because students' self-confidence becomes much higher. When the students join international students exchange program, it helps them improve their confidence (Bretag \& van der Veen, 2017).

\section{The Challenges of Joining International Students Exchange Program in the Process of Language Learning}

In this study, the researchers found several findings dealing with students' voices about the challenges of joining international students exchange program in the process of learning English language. The first finding is do not understand the local language. The second finding is struggling to communicate with local people outside of campus. The last finding is experiencing culture shock. The finding about the challenges of joining international students exchange program is described as follows:

Do not understand the local language. From the result of interview, students do not understand the local language of the country. It was stated by all participants of this study. The first statement was stated by Okta. She said, "We do not know the local language.". The second statement was stated by Amira. She said, "At first, I had a little difficulty in communicating, because everyone around me spoke with the local language." She also stated, "In the city where we live, the environment spoke with the local language." The last statement was stated by Mukti. He said, "At first, we could not speak Mandarin." He also stated, "We could not speak Mandarin.”

The statements above showed that those participants do not understand the local language of the country. The finding is in line with Altbach (2015), who stated that students have difficulty to understand the local language of the country that they visit. When the students 
join international students exchange program, it leads them to face difficulties with the language (Gautam et al., 2016).

Struggling to communicate with local people outside of campus. From the result of the interview, students struggle to communicate with the local people outside of campus. It was stated by all of the participants of this study. The first statement was stated by Okta. She said, "We struggled to communicate with the local people of the country, especially outside of the campus area." She also stated, "To communicate with the local people outside of campus, I used Google Translate as an intermediary. We said something using English, then translated it to Mandarin." She also stated that communication with the local people of the country was a struggle and a challenge. The second statement was stated by Amira. She stated, "If we were outside campus, we communicated using Google Translate.” The last statement was stated by Mukti. He said, "We were a little confused on how to communicate with the local Chinese people." He also stated, "The problem was also about communication, especially the communication with the local people outside of campus environment."

The statement above showed that all participants mentioned that students struggle in communicating with the local people outside of campus environment. International students face obstacles such as difficulties related to language and communicating with residents (Gautam et al., 2016). When the students join international students exchange program, communication with the local people of the country would be one of their main struggles. In this respect, involvement in social activities for international students with local people is demanding and to some degree, they require facilitation for university base (Gautam et al., 2016).

Experienced culture shock. The findings showed that joining international students exchange program makes students experienced culture shock. It was stated by two participants. The first statement was stated by Okta. She said, "It turns out that culture shock exists. It began with different language and different customs.”. The second statement was stated by Mukti. He said, "When I arrived there, I was quite shocked because of cultural difference". He also said, "The problem is culture shock".

The statements above showed that both participants faced culture shock in the foreign country. The finding is in line with Zhou et al. (2008), who affirmed that students who come to universities in languages and cultures that are different from their own must compete with new 
habits and new education, behavior and expectations - and deal with general adjustment challenges.

\section{Conclusion and Implication}

In this research, the researchers found five findings related to the students' voices about the benefits of joining international students exchange program. They include getting international friends, possessing better opportunity to interact with English native speakers, having plentiful time to practice their English ability, improving their English ability, and boosting their self-confidence. This research also found three findings related to the challenges of joining international students exchange program. They cover facing difficulties to understand the local language, struggling in communicating with local people outside of campus, and experiencing culture shocked.

The benefits of joining international students are significant. By then, some implication can be proposed. Students should gain such benefits so that any related parties are better to fully support student to obtain such exposures. However, the perceived challenges should be addressed appropriately to anticipate the failures of the programs. All related groups including students, host university, university senders and the committee of the program should prepare the activities carefully and attentively starting from the planning, preparation, implementation, evaluation, and follow up of the program.

\section{References}

Altbach, P. (2015). Foreign study: Patterns and challenges. International Higher Education, (30).

Andrade, M. S. (2006). International students in English-speaking universities: Adjustment factors. Journal of Research in International Education, 5(2), 131-154.

Bachner, D., \& Zeutschel, U. (2009). Long-term effects of international educational youth exchange. Intercultural Education, 20(sup1), S45-S58.

Barrow, L., \& Markman-Pithers, L. (2016). Supporting young English learners in the United States. The Future of Children, 159-183.

Berg, M. V., Paige, R. M., \& Lou, K. H. (2012). Student learning abroad: What our students are learning, what they're not, and what we can do about it. Stylus Publishing, LLC. 
Bretag, T., \& van der Veen, R. (2017). 'Pushing the boundaries': Participant motivation and self-reported benefits of short-term international study tours. Innovations in Education and Teaching International, 54(3), 175-183.

https://doi.org/10.1080/14703297.2015.1118397

Busche, S. (2017). Advantages \& challenges: An assessment of SUNY Oneonta's current approach to international student services. Capstone Collection.

https://digitalcollections.sit.edu/capstones/3060

DeKeyser, R. M. (2018). The role of practice within second language acquisition. In Practice in Second Language Learning (pp. 30-52). Cambridge University Press.

Doyle, L., McCabe, C., Keogh, B., Brady, A., \& McCann, M. (2020). An overview of the qualitative descriptive design within nursing research. Journal of Research in Nursing, 25(5), 443-455. https://doi.org/10.1177/1744987119880234

Earnest, D. R., Rosenbusch, K., Wallace-Williams, D., \& Keim, A. C. (2016). Study abroad in psychology: Increasing cultural competencies through experiential learning. Teaching of Psychology, 43(1), 75-79. https://doi.org/10.1177/0098628315620889

Gammonley, D., Rotabi, K. S., \& Rotabi, K. S. (2007). Enhancing global understanding with study abroad: Ethically grounded approaches to international learning. Journal of Teaching in Social Work, 27(3-4), 115-135. https://doi.org/10.1300/J067v27n03_08

Gautam, C., Lowery, C. L., Mays, C., \& Durant, D. (2016). Challenges for global learners: A qualitative study of the concerns and difficulties of international students. Journal of International Students, 6(2), 501-526. https://doi.org/10.32674/jis.v6i2.368

Hendrickson, B. (2018). Intercultural connectors: Explaining the influence of extra-curricular activities and tutor programs on international student friendship network development. International Journal of Intercultural Relations, 63, 1-16. https://doi.org/10.1016/j.ijintrel.2017.11.002

Hernandez, T. (2016). Short-term study abroad: Perspectives on speaking gains and language contact. Applied Language Learning, 26(1), 39-64. 
Huang, C. S. J., Yang, S. J. H., Chiang, T. H. C., \& Su, A. Y. S. (2016). Effects of situated mobile learning approach on learning motivation and performance of EFL students. Educational Technology EO Society, 19(1), 263-276.

Isabelli-García, C., Bown, J., Plews, J. L., \& Dewey, D. P. (2018). Language learning and study abroad. Language Teaching, 51(4), 439-484. https://doi.org/10.1017/S026144481800023X

Jackson, J. (2017). The personal, linguistic, and intercultural development of Chinese sojourners in an English-speaking country: The impact of language attitudes, motivation, and agency. Study Abroad Research in Second Language Acquisition and International Education, 2(1), 80-106. https://doi.org/10.1075/sar.2.1.04jac

Johnson, L. R., Seifen-Adkins, T., Sandhu, D. S., Nadezda, A., \& Makino, H. (2018). Developing culturally responsive program to promote international student adjustment: A participatory approach. Journal of International Students, 8(4), 1865-1878. https://doi.org/10.5281/zenodo. 1468100

Krishnan, L. A., Masters, C., Holgate, H., Wang, C., \& Calahan, C. A. (2017). Structured study abroad enhances intercultural competence. Teaching and Learning in Communication Sciences $\mathbb{E}$ Disorders, 1(1), 1-26. https://doi.org/10.30707/TLCSD1.1Krishnan

Lambert, V. A., \& Lambert, C. E. (2012). Qualitative descriptive research: An acceptable design. Journal of Nursing Research, 16(4), 255-256.

Lindsey, E. W. (2005). Study abroad and values development in social work students. Journal of Social Work Education, 41(2), 229-249. https://doi.org/10.5175/JSWE.2005.200303110

Llanes, À., Arnó, E., \& Mancho-Barés, G. (2016). Erasmus students using English as a lingua franca: Does study abroad in a non-English-speaking country improve L2 English? The Language Learning Journal, 44(3), 292-303. https://doi.org/10.1080/09571736.2016.1198099

Magilvy, J. K., \& Thomas, E. (2009). A first qualitative project: Qualitative descriptive design for novice researchers. Journal for Specialists in Pediatric Nursing, 14(4), 298-300. https://doi.org/10.1111/j.1744-6155.2009.00212.x 
Martin-Rubió, X., \& Cots, J. M. (2018). Self-confidence amongst study abroad students in an 'English as a lingua franca' university. Language Awareness, 27(1-2), 96-112. https://doi.org/10.1080/09658416.2018.1435673

McKay, S. L. (2018). English as an international language: What it is and what it means for pedagogy. RELC Journal, 49(1), 9-23. https://doi.org/10.1177/0033688217738817

Meng, Q., Zhu, C., \& Cao, C. (2018). Chinese international students' social connectedness, social and academic adaptation: The mediating role of global competence. Higher Education, 75(1), 131-147. https://doi.org/10.1007/s10734-017-0129-x

Quezada, R. L. (2004). Beyond educational tourism: Lessons learned while student teaching abroad. Internasional Education Journal, 5(4), 458-465.

Takehara, S., Wright, F., Kawaguchi, Y., Morio, I., Ishida, Y., \& Tagami, J. (2018). The impact of outbound exchange programs on Japanese dental students. Journal of Medical and Dental Sciences, 65(2), 99-105. https://doi.org/10.11480/jmds.650207

Thompson, A. S., \& Lee, J. (2014). The impact of experience abroad and language proficiency on language learning anxiety. TESOL Quarterly, 48(2), 252-274.

https://doi.org/10.1002/tesq.125

Trentman, E. (2013). Arabic and English during study abroad in Cairo, Egypt: Issues of access and use. The Modern Language Journal, 97(2). 457-473. https://doi.org/10.1111/j.15404781.2013.12013.x

Vögtle, E. M., \& Windzio, M. (2016). Networks of international student mobility: Enlargement and consolidation of the European transnational education space? Higher Education, 72(6), 723-741. https://doi.org/10.1007/s10734-015-9972-9

Waibel, S., Petzold, K., \& Rüger, H. (2018). Occupational status benefits of studying abroad and the role of occupational specificity - A propensity score matching approach. Social Science Research, 74, 45-61. https://doi.org/10.1016/j.ssresearch.2018.05.006

Wilkinson, S. (2000). Emerging questions about study abroad. ADFL Bulletin, 32(1), 36-41. 
Wright, C., \& Schartner, A. (2013). 'I can't ... I won't?' International students at the threshold of social interaction. Journal of Research in International Education, 12(2), 113-128. https://doi.org/10.1177/1475240913491055

Zhang, Z. (2018). English-medium instruction policies in China: Internationalisation of higher education. Journal of Multilingual and Multicultural Development, 39(6), 542-555. https://doi.org/10.1080/01434632.2017.1404070

Zhou, Y., Jindal-Snape, D., Topping, K., \& Todman, J. (2008). Theoretical models of culture shock and adaptation in international students in higher education. Studies in Higher Education, 33(1), 63-75 